\title{
Influence of Luxury Fashion Brand Index on Purchase Evaluation: Insights from the Consumers of Indian Market
}

\author{
Ritu Malhotra ${ }^{1, *}$, Sweta Choudhury ${ }^{2}$ \\ ${ }^{1}$ Department of Fashion Management Studies, National Institute of Fashion Technology (NIFT), India \\ ${ }^{2}$ Sabyasachi Couture, India
}

Copyright $(2017$ by authors, all rights reserved. Authors agree that this article remains permanently open access under the terms of the Creative Commons Attribution License 4.0 International License

\begin{abstract}
This research examined the factors that influence consumers' purchase intention behind acquiring luxury fashion brand. The study adapted the priori established scale of brand luxury index [BLI] from the literature and tested whether these dimensions result in purchase evaluation for both male and female consumers on equal grounds. Very limited research has been conducted on the role of gender differences in consumer behaviour in spite of the fact that it is a vital topic. Data was collected from Indian consumers $(n=109)$ and respondents were enquired about their favourite luxury brand in the category of watches, bags, perfumes, sunglasses, belts, tops, shirts, jeans, dresses, and footwear; while examining the dimensions such as perceived hedonism, self-image, quality, uniqueness, and conspicuousness. Hypotheses were tested using one-way ANOVA. The findings from this exploratory research revealed that perceived self-image facet is significantly different for both male and female consumers, thus indicating the vital managerial inference towards the adaption of appropriate brand positioning and marketing communication strategy. The study on the application of brand luxury index for fashion product category keeping in consideration gender differences is a new idea. Moreover, Indian consumer using luxury products is sparsely addressed in the existing literature, thereby providing motivation for this study.
\end{abstract}

Keywords Brand Luxury Index, Fashion Product Category, Purchase Intention, Gender Differences, Self-image, Indian Consumers

\section{Introduction}

In both academics and praxis, luxury branding has become an eminent topic of discussion. Luxury is considered as desirable, hence, it is more than obligatory and simple. Contrary to necessary, luxury is often considered as unnecessary and superfluous by many researchers [1-4]. Luxury products enable consumers to satisfy psychological and functional needs, and it seems that these psychological benefits are the primary aspects that differentiate them from non-luxury products or counterfeits [5]. Kapferer presented the meaning of the word 'luxury' by combining it with sociological and matter-of-fact perspective:

"Luxury defines beauty; it is art applied to functional items. Like light, luxury is en-lightening. They offer more than mere objects: they provide reference of good taste. That is why luxury management should not only depend on customer expectations: luxury brands are animated by their internal programme, their global vision, the specific taste which they promote as well as the pursuit of their own standards ... Luxury items provide extra pleasure and flatter all senses at once ... Luxury is the appendage of the ruling classes." [6]

Double digit growth in India's luxury market has drawn attention from various global luxury brands since 2011. As per the CII-Kantar IMRB report, the factors affecting growth have remarkably contributed to 25 percent growth of the luxury market of India during 2015-2016, which led to the increase of the total earning from USD 14.7 billion to a whopping USD 18.5 billion. Though globally India is one of the smaller markets in value terms, its growing number of high net worth individuals and their strong appetite for luxury products ensure that the market witnesses one of the strongest growth rates in the Asia Pacific region. With the increase in disposable income, growth of modern retailing, and impact of Western culture, a solid platform has developed for assured growth in the market of luxury growths. Studies have not examined the brand luxury index [BLI], hedonism, self-image, quality, uniqueness, and conspicuousness in relation to the emerging market, particularly, when Indian luxury clients are viewed 
differently as opposed to western markets. Further, gender is one of the most common forms of segmentation used by marketers. However, on the ground of consumer behaviour, data collected on the basis of gender difference is not enough. According to the doctrine of evolutionary psychology, this paper helps in filling the above-mentioned gap, while testing the dimensions on fashion luxury brand consumers. Thus, this research is phased in two stages. In the first stage, this study adapts the brand luxury index developed by authors [7] in relation to fashion product category, hypothesizes the relationship of brand luxury products with consumer's purchase evaluation, and argues that these perceived dimensions are not gender-biased. In total five hypotheses have been proposed in different stages of the research. In the second stage, these hypothesized relationships are tested using one-way analysis of variance (ANOVA). Thus, this paper seeks to address the following central question:

- What is the influence of perceived luxury fashion brand index on consumer's purchase evaluation?

- Can these dimensions be gender-biased in the case of luxury fashion brand?

\section{Literature Review and Hypotheses Development}

In order to address the above questions, this paper develops and tests theoretical explanations emerging from BLI on purchase evaluation, thereby evaluating them gender-wise.

\subsection{Influence of Perceived Hedonism on Purchase Evaluation}

'Hedonic dimension' is used to refer to the luxury dimension, which gets reflected by sensory gratification [8] and sensory pleasure [9]. Luxury-seekers are considered as hedonic consumers because they look for personal satisfaction through the purchase and consumption of products that provide subjective emotional benefits and are endowed with intrinsically pleasing properties, rather than functional benefits as expected from consumption [10] and [11]. Hanzaee et al. referred to the experiential value as hedonic value and described it as the positive emotional experience that arises from consumption, which in turn attracts consumers toward luxury products [12]. Hirschman and Holbrook [9] defined hedonic consumption as those aspects of consumer behavior that are associated with the experience of using product, and this experience can be multisensory, desirous, and poignant. Therefore, buyers relying on their affective judgment actually make favorable evaluation about their purchase, which is representative of the hedonic type of consumer. While studies in the past have indicated that women have higher level of hedonic consumption than men do, the research is limited to shopping in general and product-dependent hedonism is viewed as a research gap [13]. Thus, on the basis of the above arguments, the following hypothesis is proposed:

H1: Influence of perceived hedonism on purchase evaluation is not gender biased.

\subsection{Influence of Perceived Self-image on Purchase Evaluation}

A person is aware about oneself and one's outlook, opinion, discernment, and assessment of oneself as object [14] and [15]. In academics as well as in practice, it is theorized that the motivation to express or present oneself can be a dominant force behind the purchase of branded products [16]. Belk's concept of 'extended-self' suggests that people try to possess those things that form a part of their identity [17]. From several researches, it is evident that consumers tend to choose brands whose images are similar to self-concept or self-images [18] and [19]. Furthermore, earlier studies have affirmed that, "An individual's evaluation of himself will greatly influence his behavior, and thus, the more valued the self, the more organized and consistent becomes his behaviour [20]." According to Hanzaee et al., "consumers may use luxury items to integrate symbolic meaning into their own identity [12]." Consumers may probably use luxury brands not just for differentiating themselves from others, rather their objective can probably be integration of symbolic meaning related to their identity [21]. Therefore, it can further be argued that a consumer's perceived self-image interacts with the luxury brand because it is perceived that the brand is closest to their ideal self and generates a favorable subjective evaluation. Further, the characteristics associated with the traits of femininity (e.g., emotional, sensitive, expressive, nurturing) and masculinity (e.g., competitive, active, independent, instrumental) have been described as the essential psychological attributes that distinguish males from females [22]. The construct of gender-identity has received considerable attention in consumer research, however, the results obtained provide a mixed view [23-27] in explaining consumer's behavior and remains open to question. Recent study indicated that impulsive buying behavior is more dominant in women compared to men [28], however, studies have not confirmed the same toward luxury fashion brand. Therefore, hypothesis 2 examines the relationship between perceived self-image on purchase evaluation of luxury fashion brand gender-wise:

H2: Influence of perceived self-image on purchase evaluation is not gender biased.

\subsection{Influence of Perceived Quality on Purchase Evaluation}

The perceived quality construct has received considerable attention in the marketing literature [29-32]. The Theory of Reasoned Action (TRA) [33] postulates that the antecedents of purchase behavior are attitudes towards the purchase and 
subjective norm. Attitude is conceptualized here in terms of the consumer's perception of the overall quality of the brand. Research has evidenced that perceived quality has an explicit positive influence on attitude, thereby implying that if a brand is considered as high in quality, the extension of the brand also benefits; but if the associated brand is considered an inferior, then the extension is also affected [32]. Luxury brands may be perceived as more valuable by the consumers owing to the presumption that those products have greater brand quality and reassurance [34]. Earlier studies have the objective of determining the factors affecting the purchase of luxury goods by consumers and particularly considering the collective impact of brand and its Country of Origin ( $\mathrm{CoO})$ on the purchasing decision with respect to both luxury and non-luxury goods based on the maturity of luxury market [35]. The country of origin of a product strongly impact purchase of luxury goods. [36]. The influence of perceived quality and gender-differences on luxury brand evaluation has received limited attention, therefore, on the basis of the above arguments, we posit following hypothesis:

H3: Influence of perceived quality on purchase evaluation is not gender biased.

\subsection{Influence of Perceived Uniqueness on Purchase Evaluation}

Individuals express a 'need for uniqueness' [37] when they are searching for something that is difficult to obtain (for example, a Louis Vuitton hand- bag). Marketers apply scarcity strategies for affecting the decision making process of customers. Products of many famous brands are designed and marketed as limited edition products with the objective of aggravating consumer desire and intent of buying those products. [38]. Authors [39] aimed at developing a perception of purchase intention for luxury brands through scrutinization of factors that affect the purchase intentions of consumers belonging to either Eastern or Western cultures; these factors are exclusivity, self-monitoring, emotional and social attitudes. Authors [37] examined the fundamental relationship between Japanese Generation Y consumers and their intention behind purchasing US apparel brand depending on the exclusivity and consumers' awareness about the brand, and observed that purchase intention is influenced by emotional value. Thus, based on the above arguments, the following hypothesis is proposed:

H4: Influence of perceived uniqueness on purchase evaluation is not gender biased.

\subsection{Influence of Perceived Conspicuousness on Purchase Evaluation}

Conspicuousness is measured on the basis of items like 'extremely expensive' or 'for wealthy' that demonstrate the perceptions and status associated with price of a product and brand [40]. Products have been known to possess symbolic or conspicuous consumption value and may predict consumption behaviour as indicated in a study on preferring one brand of cigarette over another [41]. Authors [42] confirmed that the status-laden brands are chosen for status and conspicuous consumption, and this indicated that the consumer market, which is status-conscious, is impacted by a brand's symbolic characteristics. In a recent study [43] on the reasons behind possessing luxury products by male and female consumers revealed that both men and women use conspicuous luxury products, but for different reasons; men use it for attracting mates, whereas women use it for dissuading their female competitors, thereby indicating the novel aspect related to signaling function in relationships. Conspicuous consumption is affected by interpersonal influences in a study that assesses the relationship between status consumption and conspicuous consumption [44]. Therefore, hypothesis 5 is associated with conspicuousness and purchase intention for luxury fashion brand consumers of emerging market.

H5: Influence of perceived conspicuousness on purchase evaluation is not gender biased.

\section{Methodology}

The present exploratory study employed survey research method to brand luxury index on purchase evaluation of consumers from India and further hypothesized that the effect of perceived dimensions would not differ gender-wise. The collection of data was made from loyal customers under relevant categories based on convenience. For the category of luxury fashion product, we considered watches, bags, perfumes, sunglasses, belts, tops, shirts, jeans, dresses, and footwear.

\subsection{Respondents}

Questionnaires were filled by the respondents mainly from metropolitan cities of India. We considered respondents having luxury fashion products for collecting data on purchase intention of luxury goods. The respondents were asked to mention the luxury brands they possessed in the relevant fashion product categories. The most desirable brands that were stated by the consumers were Hublot, Louis Vuitton, Burberry, Ray Ban, Ralph Lauren, Givenchy, Prada, Miu Miu, respectively. In order to gather data, we distributed questionnaires. Among the 120 returned questionnaires, 11 were rejected because some items were left blank. Thus, there was a final usable response rate of $90.8 \%$ (109 usable responses). Of the total sample, $51 \%$ were females and constitute of respondents of different age groups; $48.62 \%$ were aged between $21-25$ years, $33.03 \%$ were aged between $26-30$ years, $15.60 \%$ were aged between $31-35$ years, and $2.75 \%$ were aged below 20 years.

\subsection{Questionnaire and Survey Administration}

The questionnaire was divided into three main sections. Section I was used for the purpose of screening based on the 
condition that the clients should own luxury fashion brands, as it enabled us to ensure that luxury fashion consumers were tapped for the survey. The consumers had to opt or mention the luxury fashion brand they owned in the relevant category of fashion product. Section II was used to gather preliminary information about consumer's demographic information. Section III consisted of six parts that captured the dimensions for this study using BLI.

\subsection{Measures}

The study used established measures from a priori literature with minor modifications to adjust with the context. Initial assessment of scales was performed by calculating the reliability for each scale with Cronbach's alpha reliability coefficient value $(\alpha>0.7)$. Scale reliabilities met or exceeded the performance of the scales in previous research.

\subsection{Data Analysis}

The analysis was done in two phases. In the first phase, the exploratory factor analysis was used for evaluating those constructs proposed in the literature that actually influence the purchase intention of consumers in the emerging market context. In the second phase, the formulated hypotheses explaining the relationships among the variables presented in the model were analysed to test the gender-wise difference related to the dimensions for luxury fashion product categories using one-way analysis of variance (ANOVA).

\subsubsection{Data Analysis: Phase I}

Exploratory factor analysis (with rotated factor matrix) was conducted to identify the scales used for measuring the study constructs by forming separate factors. The principle component factor analysis (PCFA) with varimax rotation was performed, and through this analysis six factors were extracted. The factor solution showed a KMO of 0.885 with statistically significant Bartlett's test at $1 \%$ level of significance. The six-factor solution provided an explanation for approximately $69.77 \%$ of the variance; and the Eigen values for all the factors were above 1 . All the factors were found to have reasonably high level of internal consistency reliability measured through Cronbach's alpha.

\subsubsection{Data Analysis: Phase II}

The hypothesis tests in the study were carried out using one-way ANOVA (table $1 \& 2$ ). One Way ANOVA is used when the dependency of one factor is tested across two samples. In the research, the dimensions of the luxury fashion brand are considered as the dependent factor and gender is considered differently as the grouping value for the one-way ANOVA test.

Table 1. ANOVA of Dimensions and Gender

\begin{tabular}{|c|c|c|c|c|c|c|}
\hline & & Sum of Squares & df & Mean Square & $\mathrm{F}$ & Sig. \\
\hline \multirow[t]{3}{*}{ Perceived Hedonism } & Between Groups & 0.392 & 1 & 0.392 & 0.390 & 0.534 \\
\hline & Within Groups & 107.608 & 107 & 1.006 & & \\
\hline & Total & 108.000 & 108 & & & \\
\hline \multirow[t]{3}{*}{ Perceived Self - Image } & Between Groups & 4.908 & 1 & 4.908 & 5.094 & 0.026 \\
\hline & Within Groups & 103.092 & 107 & 0.963 & & \\
\hline & Total & 108.000 & 108 & & & \\
\hline \multirow[t]{3}{*}{ Perceived Quality } & Between Groups & 0.005 & 1 & 0.005 & 0.005 & 0.945 \\
\hline & Within Groups & 107.995 & 107 & 1.009 & & \\
\hline & Total & 108.000 & 108 & & & \\
\hline \multirow[t]{3}{*}{ Perceived Uniqueness } & Between Groups & 0.761 & 1 & 0.761 & 0.759 & 0.386 \\
\hline & Within Groups & 107.239 & 107 & 1.002 & & \\
\hline & Total & 108.000 & 108 & & & \\
\hline \multirow[t]{3}{*}{ Perceived Conspicuousness } & Between Groups & 1.322 & 1 & 1.322 & 1.326 & 0.252 \\
\hline & Within Groups & 106.678 & 107 & 0.997 & & \\
\hline & Total & 108.000 & 108 & & & \\
\hline
\end{tabular}


Table 2. Results of one-way ANOVA

\begin{tabular}{|c|c|c|}
\hline $\mathrm{H}_{1}$ : & Influence of perceived hedonism on purchase evaluation is not gender biased. & \multirow{2}{*}{$\begin{array}{l}\text { sig. } 0.534>0.05 \\
\text { Therefore, } H_{1} \text { is accepted }\end{array}$} \\
\hline $\mathrm{H}_{0}$ : & $\mu \mathrm{hm}=\mu \mathrm{hf}$ & \\
\hline $\mathrm{H}_{2}$ : & Influence of perceived self-image on purchase evaluation is not gender biased & \multirow{2}{*}{$\begin{array}{c}\text { sig. } 0.026<0.05 \\
\text { Therefore, } \mathrm{H}_{2} \text { is rejected. }\end{array}$} \\
\hline $\mathrm{H}_{0}$ : & $\mu \mathrm{sm}=\mu \mathrm{sf}$ & \\
\hline $\mathrm{H}_{3}:$ & Influence of perceived quality on purchase evaluation is not gender biased & \multirow{2}{*}{$\begin{array}{l}\text { sig. } 0.945>0.05 \\
\text { Therefore, } \mathrm{H}_{3} \text { is accepted. }\end{array}$} \\
\hline $\mathrm{H}_{0}$ : & $\mu \mathrm{sm}=\mu \mathrm{sf}$ & \\
\hline $\mathrm{H}_{4}:$ & Influence of perceived uniqueness on purchase evaluation is not gender biased & \multirow{2}{*}{$\begin{array}{l}\text { sig. } 0.386>0.05 \\
\text { Therefore, } \mathrm{H}_{4} \text { is accepted. }\end{array}$} \\
\hline $\mathrm{H}_{0}$ : & $\mu \mathrm{sm}=\mu \mathrm{sf}$ & \\
\hline $\mathrm{H}_{5}:$ & Influence of perceived conspicuous on purchase evaluation is not gender biased. & \multirow{2}{*}{$\begin{array}{l}\text { sig. } 0.252>0.05 \\
\text { Therefore, } \mathrm{H}_{5} \text { is accepted }\end{array}$} \\
\hline $\mathrm{H}_{0}$ : & $\mu \mathrm{sm}=\mu \mathrm{sf}$ & \\
\hline
\end{tabular}

The above table 1 and 2 show the output of the ANOVA analysis and whether there is a statistically significant difference between our group means. We can see that the significance value in hypothesis 2 is 0.026 (i.e., $p=.026$ ), which is below 0.05 and, therefore, there is a statistically significant difference in the mean length. From the results, we know that there are statistically significant differences between the gender groups as a whole. The table 1 above, shows that the groups including male and female gender differed from each other. However, there were no differences between the groups for hypothesis $1,3,4$, and 5 with significance value which is above 0.05 a depicted in table 2 (i.e., $p=0.534, p=0.945, p=0.386, p=0.252$ for $\mathrm{H}_{1}$, $\mathrm{H}_{3}, \mathrm{H}_{4}, \mathrm{H}_{5}$ respectively). Thus, based on the results above, we report that there was a statistically significant difference between gender groups for perceived self-image dimension.

\section{Conclusions}

The implications of this research are of significance for marketers and scholars in the field of luxury brands. The results of this research could serve various purposes, and can perhaps be specifically applied to build brand luxury in the context of an emerging market. The study rejected the hypothesis that the influence of perceived self-image on purchase evaluation is not gender-biased. This implies that male and female consumers have different perception about their self-image towards luxury fashion brand. This study addressed the most crucial question: Should marketers invest resources in communication channels with the focus to enhance self-image, experiential marketing, and channelize brand value through consumers' cognitive dimensions? This study provided insight about the consumers of Indian luxury fashion goods by focusing on the concept of BLI as experienced by both male and female related to the purchase evaluation pattern. Perceived self-image differs significantly between genders in the case of luxury goods, but there is no significant difference between genders related to perceived hedonism, quality, uniqueness, and conspicuousness. It is important for practitioners to focus on the findings from the consumers of emerging markets. In order to explain this counter-intuitive outcome, the rationale could be drawn from the fact that India is a culturally different setting and inferences from western or Asian market cannot be generalized to Indian market. For developing promotion approach, the finding assists in building an emotional relation between brand and consumer with regard to their gender.

In light of the above results, the present study is a pioneer in contributing to the three aspects related to luxury literature. First, this research aimed at empirically investigating Vigneron and Johnson's BLI to evaluate purchase intention. The present research revealed that the concept of luxury is multidimensional and applied the same for luxury fashion consumer of emerging market. Second, the scale was originally developed and validated using data from business students. However, the analysis of the present data is collected from actual Indian consumers for validating the psychometric properties of scale and its equivalence across cultures. Third, in establishing the relationship of BLI and examining gender differences, it is observed that gender is one of the most common forms of segmentation used by marketers.

\section{REFERENCES}

[1] Heine, K. and Phan, M., Trading-up mass-market goods to luxury products, Australasian Marketing Journal, Vol. 19 No. 2, pp. 108-114, 2011.

[2] Dubois, B., Laurent, G. and Czellar, S., Consumer rapport to luxury: Analyzing complex and ambivalent attitudes, Consumer Research Working Paper No. 736, HEC, Jouy-en-Josas, France, 2001.

[3] Csaba, F.F., Redefining luxury: A review essay, Creative Encounters, Vol. 15, pp. 1-32, 2008.

[4] Jäckel, M. \& Kochhan, C., Notwendigkeit und Luxus: Ein Beitrag zur Geschichte des Konsums, in Rosenkranz, D. and Schneider, N.F. (Eds), Konsum - Soziologische, ökonomische und psychologische Perspektiven, Opladen, pp. 73-93, 2000. 
[5] Arghavan, N. and Zaichkowsky, J., Do Counterfeits devalue the ownership of luxury brands?, Journal of Product and Brand Management, Vol. 9 No. 7, pp. 485-497, 2000.

[6] Kapferer, J.N., Managing Luxury Brands, Journal of Brand Management, Vol. 4 No. 4, pp. 251-260, 1997.

[7] Vigneron , F. and Johnson, L.W., Measuring perceptions of brand luxury. Journal of Brand Management, Vol. 11 No. 6, pp. 484-506, 2004.

[8] Rossiter, J.R. \& Percy, L., Advertising Communications and Promotion Management (2nd Ed.). New York, NY: McGraw Hill, 1997.

[9] Hirschman, E.C. and Holbrook, M.B., Hedonic consumption: emerging concepts, methods and propositions, The Journal of Marketing, Vol. 46 No. 3, pp. 92-101, 1982.

[10] Seth, J.N., Newman, B.I. and Gross, B.L., Consumption Values and Market Choices: Theory and Application, Cincinnati, OH: South-Western, 1991.

[11] Westbrook, R. A. and Oliver, R. L., The dimensionality of consumption emotion patterns and consumer satisfaction, Journal of Consumer Research, Vol. 18 No. 1, pp. 84-91, 1991.

[12] Hanzaee, K., H., Teimourpour, B. and Teimourpour, B., Segmenting Consumers Based on Luxury Value Perceptions, Middle-East Journal of Scientific Research, Vol. 12 No. 11, pp. 1445-1453, 2012.

[13] Tifferet, S. and Herstein, R., Gender differences in brand commitment, impulse buying, and hedonic consumption, Journal of Product \& Brand Management, Vol. 21 No. 3, pp. 176-182, 2012.

[14] Hall, C.S. and Lindsay, G., Theories of Personality, New York: John Wiley and Sons Inc., 1957.

[15] Krech, D., Crutchfield, R.S. and Ballachey, E.L., Individual in Society, New York: McGraw-Hill Book Company, 1962.

[16] Aaker, J.L., The malleable self: the role of self-expression in persuasion, Journal of Marketing Research, Vol. 36 No. 1, pp. 45-57, 1999.

[17] Belk, R., Possessions and self. Wiley International Encyclopedia of Marketing, New York: Wiley, 1988.

[18] Liu, F., Li, J., Mizerski, D. and Soh, H., Self-congruity, brand attitude, and brand loyalty: a study on luxury brands, European Journal of Marketing, Vol. 46 No. 7/8, pp. 922-937, 2012.

[19] Mazodier, M. and Merunka, D., Achieving brand loyalty through sponsorship: the role of fit and self-congruity, Journal of the Academy of Marketing Research, Vol. 40 No. 6, pp. 807-820, 2012.

[20] Grubb, E.L. and Grathwohl, H.L., Consumer Self-concept, Symbolism and Market Behavior: A Theoretical Approach, Journal of Marketing, Vol. 31 No. 4, pp. 22-27, 1967.

[21] Holt, D.B., How consumers consume: A typology of consumption practices, Journal of Consumer Research, Vol. 22 No. 1, pp. 1-16, 1995.

[22] Spence, J.T. and Helmreich, R.L., Comparison of Masculine and Feminine Personality Attributes and Sex-Role Attitudes Across Age Groups, Developmental Psychology, Vol. 15 No. 5, pp. 583-584, 1979 .
[23] Fischer, E. and Arnold, S.J., More than a labor of love: Gender roles and Christmas gift shopping, Journal of Consumer Research, Vol. 17 No. 3, pp. 333-345, 1990.

[24] Fischer, E. and Arnold, S.J., Sex, gender identity, gender role attitudes, and consumer behavior, Psychology \& Marketing, Vol. 11 No. 2, pp. 163-182, 1994.

[25] Coughlin, M., \& O'Connor, P. J. (1985). Gender role portrayals in advertising: An individual differences analysis. NA-Advances in Consumer Research Volume 12.

[26] Allison, N.K., Golden, L.L., Mullet, G.M. and Coogan, D., Sex-typed Product Images: The Effects of Sex, Sex Role Self Concept, and Measurement Implications, Advances in Consumer Research, Vol. 7, pp. 604-609, 1980.

[27] Schmitt, B. H., Leclerc, F. and Dube-Rioux, L., Sex typing and consumer behavior: A test of gender schema theory, Journal of Consumer Research, Vol. 15 No. 1, pp. 122-128, 1988.

[28] Tifferet, S. and Herstein, R., Gender differences in brand commitment, impulse buying, and hedonic consumption, Journal of Product \& Brand Management, Vol. 21 No. 3, pp. $176-182,2012$

[29] Holbrook, M. B. and Corfman, K.P., Quality and value in the consumption experience: Phaedrus rides again, Perceived Quality, Vol. 31 No. 2, pp. 31-57, 1985

[30] Jacobson, R. and Aaker, D.A., The strategic role of product quality, The Journal of Marketing, Vol. 51 No. 4, pp. 31-44, 1987.

[31] Olshavsky, R.W., Perceived quality in consumer decision making: an integrated theoretical perspective, Perceived Quality, Vol. 4, pp. 3-29, 1985.

[32] Aaker, D.A. and Keller, K.L., Consumer evaluations of brand extensions, The Journal of Marketing, Vol. 54 No. 1, pp. 27-41, 1990.

[33] Ajzen, I. and Fishbein, M., Belief, attitude, intention and behavior: An introduction to theory and research, Journal of Business Venturing, Vol. 5, pp. 177-189, 1975.

[34] Aaker, D., Brand equity. La gestione del valore della marca, 1991.

[35] Godey, B., Pederzoli, D., Aiello, G., Donvito, R., Chan, P., Oh, H., ... and Weitz, B., Brand and country-of-origin effect on consumers' decision to purchase luxury products, Journal of Business Research, Vol. 65 No. 10, pp. 1461-1470, 2012.

[36] Piron, F., Consumers' perceptions of the country-of-origin effect on purchasing intentions of (in) conspicuous products, Journal of Consumer Marketing, Vol. 17 No. 4, pp. 308-321, 2000 .

[37] Snyder, C.R. and Fromkin, H.L., Abnormality as a positive characteristic: The development and validation of a scale measuring need for uniqueness, Journal of Abnormal Psychology, Vol. 86 No. 5, pp. 518-527, 1977

[38] Knight, D.K. and Young Kim, E., Japanese consumers' need for uniqueness: Effects on brand perceptions and purchase intention, Journal of Fashion Marketing and Management: An International Journal, Vol. 11 No. 2, pp. 270-280, 2007.

[39] Bian, Q. and Forsythe, S., Purchase intention for luxury brands: A cross cultural comparison, Journal of Business Research, Vol. 65 No. 10, pp. 1443-1451, 2012. 
[40] Vigneron, F. and Johnson, L.W., A review and a conceptual framework of prestige-seeking consumer behavior, Academy of Marketing Science Review, Vol. 1999 No. 1, pp. 1-15, 1999.

[41] Sheth, J.N., Newman, B.I. and Gross, B.L., Why we buy what we buy: A theory of consumption values, Journal of Business Research, Vol. 22 No. 2, pp. 159-170, 1991.
[42] O'cass, A. and Frost, H., Status brands: examining the effects of non-product-related brand associations on status and conspicuous consumption, Journal of Product \& Brand Management, Vol. 11 No. 2, pp. 67-88, 2002.

[43] Wang, Y. and Griskevicius, V., Conspicuous consumption, relationships, and rivals: Women's luxury products as signals to other women, Journal of Consumer Research, Vol. 40 No. 5 , pp. 834-854, 2014.

[44] O'cass, A. and McEwen, H., Exploring consumer status and conspicuous consumption, Journal of Consumer Behaviour, Vol. 4 No. 1, pp. 25-39, 2004. 